\title{
Faz Değiştiren Malzemelerin Bina Kabuğunda Kullanımı
}

\section{Usage in Building Envelope of Phase Change Materials}

\author{
Deniz Saylam Canım ${ }^{1}$, Sibel Maçka Kalfa*2 \\ ${ }^{1}$ Karadeniz Teknik Üniversitesi, Mimarlık Bölümü, Trabzon, dsaylam@ hotmail.com \\ ${ }^{2}$ Karadeniz Teknik Üniversitesi, Mimarlık Bölümü, Trabzon, sibelmacka@ktu.edu.tr
}

\begin{tabular}{|c|c|}
\hline MAKALE BİLGİLERİ & ÖZET \\
\hline Makale geçmişi: & \multirow{6}{*}{ 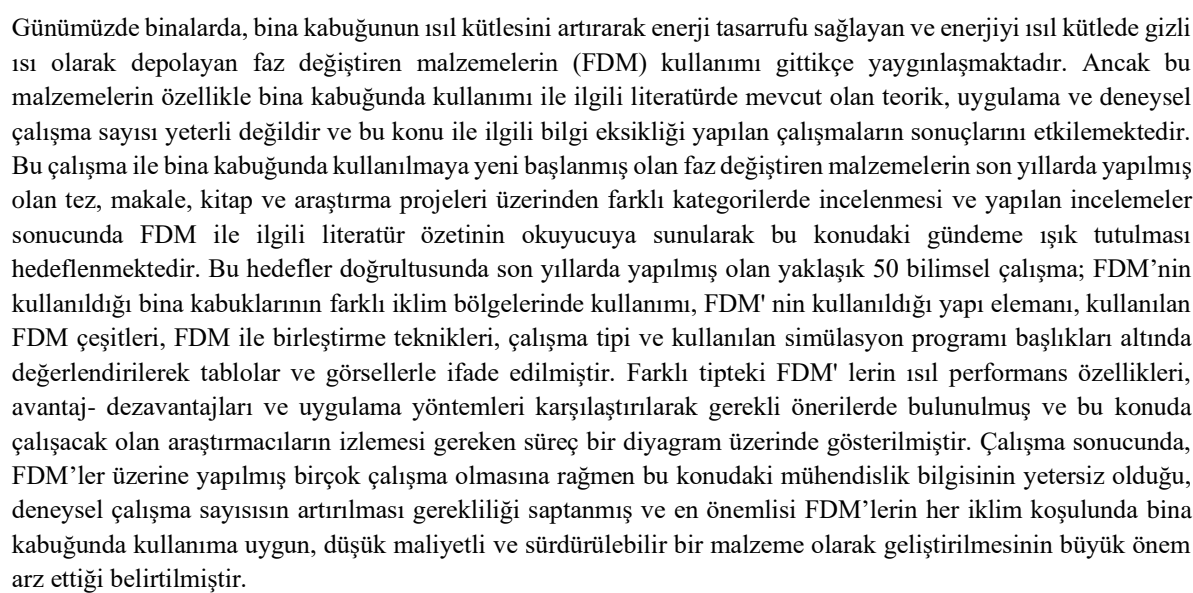 } \\
\hline $\begin{array}{l}\text { Geliş: } 11 \text { Ağustos } 2020 \\
\text { Düzeltme: } 17 \text { Eylül } 2020 \\
\text { Kabul: } 17 \text { Eylül } 2020\end{array}$ & \\
\hline Anahtar kelimeler: & \\
\hline $\begin{array}{l}\text { Faz değiştiren malzeme, bina } \\
\text { kabuğu, trombe duvar, parafin, yağ }\end{array}$ & \\
\hline & \\
\hline & \\
\hline
\end{tabular}

Doi: 10.24012/dumf.779147

\begin{tabular}{ll}
\hline ARTICLE INFO & $\begin{array}{l}\text { ABSTRACT } \\
\text { Article history: }\end{array}$ \\
$\begin{array}{l}\text { Received: } 11 \text { August } 2020 \\
\text { Revised: } 17 \text { September } 2020 \\
\text { Accepted: } 17 \text { September } 2020\end{array}$ & $\begin{array}{l}\text { poways, the use of phase-changing materials (PCM) which store energy as latent heat in the thermal mass and } \\
\text { puildings. However, in literature, the number of theoretical, practical and experimental study on using in building } \\
\text { envelope of these materials is not enough and lack of information in relation to this topic effects results of similar } \\
\text { studies. With this study, it is aimed to examine the phase-changing materials that have just started to be used in } \\
\text { the building envelope in different categories through thesis, articles, books, and research projects made in recent } \\
\text { Keywords: }\end{array}$ \\
$\begin{array}{l}\text { years and to shed light on the agenda by means of present a summary of the literature on PCM to the reader in } \\
\text { result of these examinations. In line with these targets; approximately 50 scientific studies published in recent } \\
\text { fatty acids }\end{array}$ & $\begin{array}{l}\text { years; Usage in different climatic regions of building envelopes with PCM, the building element where the PCM } \\
\text { is used, the PCM types used, the joining techniques with PCM, the study type and the simulation program used } \\
\text { are evaluated and expressed with tables and visuals. By comparing the thermal performance characteristics, } \\
\text { advantages-disadvantages and application methods of different types of PCMs, the necessary suggestions were } \\
\text { made and the process that should be followed by the researchers who will work on this subject is shown on a } \\
\text { diagram. As a result of the study, although there are many studies on PCMs, it was determined that the engineering } \\
\text { knowledge on this subject is insufficient, the number of experimental studies should be increased, and most } \\
\text { importantly, it is of great importance to develop PCMs as a low-cost and sustainable material suitable for use in } \\
\text { building envelopes in all climatic conditions. It has been stated. }\end{array}$
\end{tabular}

\footnotetext{
* Sorumlu yazar / Correspondence

Sibel Maçka Kalfa

$\triangle$ sibelmacka@ktu.edu.tr

Please cite this article in press as D. Saylam Canım, S. Maçka Kalfa, “Faz Değiştiren Malzemelerin Bina Kabuğunda Kullanımı”, DUJE, vol. 12, no.2, pp. 355-371, March 2021.
} 


\section{Giriș}

Binalar, Avrupa'da toplam enerji kullanımının yaklaşık \% 40'ından sorumludur [1]. Isıtma ve soğutma için harcanan enerji bunun önemli bir kısmını oluşturmaktadır. Bu enerji kullanımını ve buna bağlı olumsuz çevresel etkileri azaltmak amaciyla, tüm AB / AEA üyesi ülkeler ulusal yapı düzenlemelerini Avrupa direktifine (EPBDRecast) uygun olarak revize etmiştir. EPBD 2010/31/EU kapsamında, 2020 yılında tüm Avrupa Birliğinin karbon salınımının 1990 y1lındaki seviyelerin \% 20 altına düşmesi, tüm enerji tüketiminin \% 20 azaltılması, kullanılan enerjinin \%20'sinin yenilenebilir kaynaklardan sağlanması ve tüm binaların neredeyse sıfır enerjili olması hedefleri belirlenmiştir [2]. Enerji kaynaklarını sağlama bakımından yüksek oranda dışa bağımlı olan Türkiye için de binalarda enerji performansını artırmak büyük önem taşımaktadır. Bu amaçla Türkiye Ulusal Enerji Verimliliği Eylem Planını hazırlamış, bu plan kapsamında da 2023 yılına kadar toplam enerji tüketiminin \%20 oranında azaltılacağı ve bunda yenilenebilir enerji kaynaklarının kullanılmasının önemli bir payı olacağı öngörülmüştür [3]. Avrupa'da belirlenen hedeflere ulaşabilmek ve enerji talebini en aza indirmek için daha yüksek 1sı yalıtım seviyeleri ve hafif binalar teşvik edilmektedir [2]. Hafif binaların en büyük dezavantajı düşük 1sıl kütleleri ve 1sitma-soğutma yükleri nedeniyle yüksek sıcaklık dalgalanmalarına meyilli olmalarıdır. $\mathrm{Bu}$ dezavantajları asgari düzeye indirebilmek için son yıllarda hafif binaların 1sıl kütlelerini artırarak enerji tasarrufu sağlayan ve enerjiyi ısıl kütlede gizli 1sı olarak depolayan faz değiştiren malzemelerin (FDM) kullanımı büyük ilgi görmektedir. Gizli 1s1 depolama 1s1 enerjisini depolamanın en etkili yollarından biridir [4]. $\mathrm{Su} /$ buz yaklaşık $330 \mathrm{kj} / \mathrm{kg}^{\prime}$ lik gizli 1sısı ile insan çevresinde terk edilmiş olarak bulunan en iyi bilinen FDM'dir. Bu nedenle kuzey kutup bölgelerinde yaşayan halk geleneksel yapıları olan igloların yapımında yüzyıllardır faz değişimi-gizli ısı konseptini kullanmaktadır. İglo yöre halkını soğuktan koruyan oldukça efektif, yapımı kolay bir malzeme olarak buz ve karın kullanıldığ 1 bir yapıdır [5]. Gonzales-Espada (2001)'ya göre diş ortam sicaklığının $-45{ }^{0} \mathrm{C}$ olduğu en sert kış aylarında bile igloların iç ortam sicaklığ $9^{0} \mathrm{C}-15^{0} \mathrm{C}$ arasında değişim göstermektedir [6]. İglolardan yola çıkarak araştırmaların hız kazandığı FDM'ler ilk kez 1948 yılında Massachusetts Enstitüsündeki Araştırmacı Dr. Maria Telkes tarafindan Amerika'nın Massachusetts şehrinde bulunan bir konut binasında kullanılmıştır. Bu çalışma büyük öneme sahiptir. Çünkü teorik olarak FDM'lerden oluşturulmuş duvar konstrüksiyonlarının uygulandığı bina kabuğunun enerji tüketimini azaltacağı biliniyor olmasına rağmen gerçek koşullarda FDM kullanılmış yapı elemanına sahip bina kabuğunun inşa edilmesi ile yapılan deneysel çalışmaların sayısının artması önemlidir [7]. Özellikle ülkemizde bu kapsamda FDM üzerine yapılan çalışma sayısı azdır. Bina kabuklarında kullanılan FDM'lerde iki farklı 1sı kaynağı kullanılır. Bunların birincisi doğal 1sıtma ve soğutma kaynaklarıdır. Örnek olarak 1sıtma için güneş enerjisinin, soğutma için ise gece soğuyan havanın kullanılması verilebilir. İkincisi ise yapay 1sıtma veya soğutma kaynaklarıdır. Bina kabuğu uygulamalarında soğutma amaçlı olarak faz değişim sıcaklığ $122-24{ }^{0} \mathrm{C}$ arası olan FDM' lerin kullanılması uygundur [8]. Doğrudan güneş 1şınımı ile 1sıtmada, günlük 1sı depolama için en uygun FDM faz değişim sıcaklığının ortalama oda sıcaklığının $1-3^{\circ} \mathrm{C}$ üzerinde olması gerekmektedir $[9,10]$. FDM'ler ile ilgili bilgiler yeterli değildir ve bundan kaynaklı bu konu öncelikli çalışma konuları arasındadır.

Yukarıda bahsedilen bilgiler 1şı̆̆ında bu çalışmanın amacı, FDM kullanımı ile bina kabuğunun dinamik özelliklerini ve enerji performansının değerlendirildiği literatürde yer alan çalışmaların kapsamlı bir incelemesini yapmak ve faz değiştiren malzemeleri tanıtmaktır. $\mathrm{Bu}$ amaçla çalışmada literatürde yapılmış yaklaşık 50 bilimsel çalışma; FDM'nin uygulandığı bina kabuklarının farklı iklim bölgelerinde kullanımı, FDM'nin kullanıldığ 1 yap1 elemanları, kullanılan FDM çeşitleri, FDM ile birleştirme teknikleri, yapılan çalışmaların tipi ve çalışmalarda kullanılan simülasyon programları başlıkları altında değerlendirilmiş, farklı tipteki FDM'lerin 1s1l performans çalışmaları, avantaj- dezavantajları ve uygulama yöntemleri gözden geçirilerek bu konuda çalışacak araştırmacıların izlemesi gereken süreç bir diyagram üzerine işlenmiştir. 


\section{Yöntem}

Faz değiştiren malzemeler üzerine yapılmış birçok uluslararası, ulusal makale, tez, kitap ve araştırma projesi Karadeniz Teknik Üniversitesi Kütüphanesi veri tabanları kullanılarak incelenmiştir. İncelenen bilimsel çalışmalar içerisinde bilimsel kalitesi yüksek olan (yayınevinin kuruluş yılı, atıf sayısı, etki faktörleri vb. gibi seçim kriterleri göz önünde bulundurularak) ve özellikle son y1llarda yapılmış olan yaklaşık 50 çalışma incelemeye alınmıştır. FDM üzerine yapılan çalışmalardan elde edilen bilgiler; FDM'nin uygulandığg bina kabuklarının farklı iklim bölgelerinde kullanımı, FDM'nin kullanıldığı yapı bileşeni, kullanılan FDM çeşitleri, FDM ile birleştirme teknikleri, yapılan çalışmaların tipi ve çalışmalarda kullanılan simülasyon programı başlıkları altında değerlendirilmiștir.

\section{FDM'nin Uygulandığı Bina Kabuklarının Farklı İklim Bölgelerinde Kullanımı}

İklim bölgelerine göre değerlendirildiğinde, FDM' nin soğuk iklim bölgelerinde kullanımı ile gerçekleştirilen çalışmalarda, en soğuk aylarda çok etkili olmamakla birlikte yıl bazında değerlendirildiğinde FDM ile ortalama \%20 verim elde edildiği görülmüştür. Gece ve gündüz sıcaklık farkının fazla olmadığ 1 1lıman iklim bölgelerinde ise FDM'nin bina kabuğunun dışında değil de iç tarafında kullanılmasının iç mekan 1s1 dalgalanmalarının azaltılmasi açısından daha uygun olduğu belirtilmiştir [11]. Gece ve gündüz sıcaklık farkının fazla olduğu iklim bölgelerinde ise FDM'nin bina kabuğunun dış tarafında kullanımının etkili olduğu, böylece gündüz FDM tarafindan depolanan isının soğuk gecelerde kullanılarak, bir sonraki gün yeniden iç ortama verilebilmesi sağlanmıştır $[12,13]$. FDM'lerin soğutma amacı ile kullanıldığı sicak iklim bölgelerinde gece havalandırması (4ac/h'ye kadar), binalarda FDM'nin etkinliğini en üst düzeye çıkarma yönünde avantajlara sahiptir. Gece havalandırması ile FDM'lerin depoladıkları 1 sinın ortama verilmesi desteklenerek katılaşmaları sağlanmakta böylece tam bir çalışma döngüsü elde edilebilmektedir [14].

\section{FDM'nin Kullanıldığı Yapı Elemanları}

Bina kabuğunun uzun ömürlü olabilmesi için kullanılan FDM'nin konumu, faz değişim sıcaklık aralığı ve miktarı bakımından oldukça önemlidir. Yapılan literatür incelemesi sonucu faz değiştiren malzemelerin yapının hangi elemanında ne kadar yoğunlukta kullanıldığ Şekil 1' de verilmiştir.

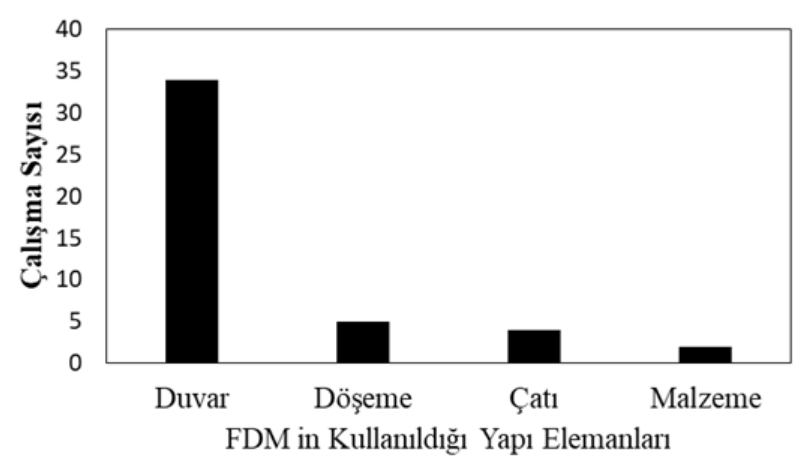

Şekil 1. FDM 'nin kullanıldı ̆̆ yapı elemanları ve kullanım yoğunluğu.

Figure 1. Building elements using of phase change material and using density

Şekil 1' deki grafikte yapılan çalışmalarda FDM ' nin en fazla dış duvar uygulamalarında kullanıldığ1 görülmektedir [8,10,11,14-41]. Bu durumun diş duvar ısıl kütle yüzey alanının çatı ve döșeme yüzey alanına göre daha fazla olmasından kaynaklandığı düşünülmektedir. Ayrıca yapılan çalışmalar FDM'nin duvar iç yüzeyine uygulandığında iç mekan 1sı dalgalanmalarını azalttığını göstermiştir $[10,11,14,20,23,30,35,36,38,39,41-47]$.

Is1 enerjisinin depolandığı pasif bir sistem olan trombe duvarının ağır 1sıl kütlesini hafifletmek ve kullanımını daha pratik hale getirmek için FDM'lerin kullanıldığı çalışmalar da mevcuttur $[8,15,17,18,34,38,48]$. FDM ile oluşturulan trombe duvarın isil kapasitesini, klasik beton duvar ile karşılaştırıldığında, ortalama \%50 artırmak mümkündür $[8,17,18]$. Faz değiştiren malzeme olarak kullanılan parafinlerin isıl iletkenliğini arttırmak için metalik dolgular, metal matris yapilar, kanatlı borular ve alüminyum talaşlar kullanılmaktadır. Kullanılan metal arttırıciların FDM asitleriyle temas halinde aşındırıcı olmamalarına binanın uzun ömürlü olması için dikkat edilmelidir $[4,13,48,49]$. FDM kullanımı ile ince bir duvarda yoğun isıl kütle 
elde etmek mümkün olmakla beraber elde edilen FDM'li duvarın zaman gecikmesi kalın beton duvara göre çok daha kısa olmaktadır. Bu durum sağlanan enerjinin odaya ortalama iki kat daha hızlı aktarılabilmesini sağlamaktadır. Fakat azalan zaman gecikmesi, gün boyunca kullanılan ofis, alışveriş merkezi, üniversite ve okul gibi yapılar için kışın bir avantaj olarak görülse de akşam kullanımı yoğun olan konut ve hastane gibi yapılar için bir dezavantaj olmaktadır. Bina dış duvarlarının iç ve dış yüzeyinde farklı faz değişim sıcaklıklarına sahip FDM kullanımı ile hem soğutmaya katkı amacı ile sıcak mevsimde hem de 1sıtmaya katkı amacı ile soğuk mevsimde aktif olması sağlanabilmektedir. Böyle bir sistemin y1llik enerji tasarrufunun 1sıtma için ortalama $\% 12$, soğutma için ise $\% 1$ oranlarında olduğu, 1sitma-soğutma yüklerinin tepe değerini \%35 oranında düşürdüğü tespit edilmiştir [19]. Gizli 1s1 depolama amaciyla kullanılan FDM'ler ile oluşturulmuş yapı elemanlarına sahip konutların ilk deneysel çalışmalarında umut verici performans artışı gözlenmiştir. FDM'nin çatıda kullanılmasıyla toplam soğutma yükünde aynı 1sıl direnç $\left(\mathrm{R}-\mathrm{m}^{2} \mathrm{~K} / \mathrm{W}\right)$ değerine sahip yalıtım katmanının kullanıldığı geleneksel çatıya oranla \%30 verim elde edilmiştir [4]. FDM'ler iç mekan 1S1 dalgalanmalarını azaltırken bina ataletini de artırdıkları için, kentsel ortamlarda karş1lıklı gölgelendirme ve yansımalar ile ortaya çıkabilen binalar arasındaki olumsuz etkileri de en aza indirmeye yardımcı olmaktadır [25]. Teorik olarak çoğu FDM entegre bina kabuğu elemanının günde en az bir kere erime/ katılaşma süreci geçirmesi beklenir. $\mathrm{Bu}$ nedenle mümkün olduğunca az FDM kullanarak FDM'nin depolama/ birakma kapasitesini arttırmak gerekir. Yani kullanılacak FDM' nin optimizasyonu yapılmalıdır. Tam bir günlük döngüde depolanan enerji FDM hacmine orantilidir, FDM tamamen eridikten sonra, sadece hissedilir 1s1 emilir. FDM'lerin düşük 1sıl iletkenliği nedeniyle, bu sistemlerin şarj etme ve boşaltma işlemleri sırasında doğal olarak yavaş bir 1S1 transferine sebep oldukları unutulmamalıdır. FDM kütlesi fazla tahmin edilirse, 1sının FDM'ye nüfuz etmesi için gereken süre güneş 1 şığı süresinden daha büyük olabilir ve erime süreci tamamlanamaz. Benzer şekilde, eğer FDM kütlesi fazla tahmin edilirse, iç mekanlarda ısının serbest bırakılması için gereken süre, boşalma süresinden daha büyük olabilir ve katılaşma süreci tamamlanamaz.
Böylece, FDM ne erimez ne de katılaşmazsa, yetersiz gizli 1s1 depolanır [43]. Fakat unutulmamalıdır ki, hidrolik ısıtma ve soğutma sistemi ile entegre bir çok zemin ve tavan FDM uygulamaları 1 günde kolaylıkla $20 \mathrm{kez}$ erime ve katılaşma sürecine ulaşabilmektedir [4].

\section{FDM Çeşitleri}

Dar bir sıcaklık aralığında yüksek miktarda 1s1 enerjisi depolamak zorunda olan faz değiştiren malzemeler, geleneksel yapı malzemeleri (beton, taş) ile kıyaslandığında çok daha hafif olmalarına rağmen geleneksel yapı malzemelerinden 15 kat daha fazla 1siy1 birim hacimlerinde depolayabilmektedirler. $\mathrm{Bu}$ özelliğinden kaynaklı olarak FDM'ler hafif ve yüksek 1sıl kütleye sahip bina kabuğu uygulamalarında kullanıma uygun bir malzeme olarak karşımıza çıkmaktadır [4]. FDM'nin fiziksel, kimyasal ve ekonomik özellikleri, bina kabuğunda kullanıma uygunluğu için önemlidir. Tablo 1'de faz değiştiren malzemelerin fiziksel, kimyasal ve ekonomik özellikleri verilmiştir. Faz değiştiren malzemeler içerisinde Tablo 1'de verilen özelliklerin tümüne sahip bir malzeme henüz bulunamamıştır [13]. Çok çeşitli sıcaklıklarda eriyen ve katılaşan çok sayıda faz değiştiren malzeme mevcuttur. Fakat bina kabuğu uygulamalarında kullanılan FDM'ler sinırlıdır. Bunun nedeni sadece insan konfor sicaklığına $\left(20^{\circ} \mathrm{C}-28^{\circ} \mathrm{C}\right)$ yakın sıcaklıklarda faz değişimine sahip FDM'lerin bina kabuğu uygulamalarında kullanılabilmesidir. Literatür incelemesi sonucu bina kabuğu uygulamalarında kullanılan FDM çeşitleri ve kullanım yoğunlukları Şekil 2' de verilmiştir.

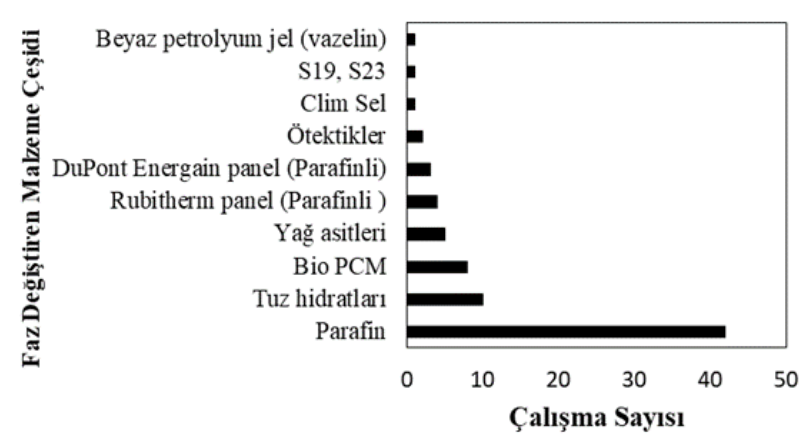

Şekil 2. Bina kabuğu uygulamalarında kullanılan FDM çeşitleri ve kullanım yoğunluğu

Figure 2. PCM types using in building envelope applications and using density 
Tablo 1. Faz değiştiren malzemelerin fiziksel, kimyasal ve ekonomik özellikleri [4,13]

Table 1. Physical, chemical and economic properties of phase change materials [4,13]

\begin{tabular}{|c|c|c|}
\hline Fiziksel Özellikler & Kimyasal Özellikler & Ekonomik özellikler \\
\hline $\begin{array}{l}\text { - Faz değişim sıcaklığı; } \\
\text { - } \quad \text { Erime-katılaştırma işlemleri için } \\
\text { minimum sıcaklık aralığ1; } \\
\text { - } \quad \text { Süper soğuma; } \\
\text { - } \quad \text { Yüksek gizli ısı geçişi; } \\
\text { - Hassas ısı emilimine ek olarak } \\
\text { - } \quad \text { Iüksek özgül ısı kapasitesi; } \\
\text { serbest bırakillması için iyi ısı } \\
\text { iletkenliği; } \\
\text { - Faz değişiklikleri sırasında } \\
\text { - } \text { hacimde küçük değişiklikler; } \\
\text { Kararlı erime ve katılaşma } \\
\text { döngüleri; } \\
\text { - Yeterli kristalleşme hızı }\end{array}$ & $\begin{array}{l}\text { Birçok erime- } \\
\text { katılaşma } \\
\text { döngüsünden } \\
\text { sonra } \\
\text { bozulmama; } \\
\text { - Diğer yapı } \\
\text { malzemeleriyle } \\
\text { iyi uyumluluk.; } \\
\text { - Yeterli mekanik } \\
\text { stabilite; } \\
\text { - Yanmaya karşı } \\
\text { dirençlilik }\end{array}$ & $\begin{array}{l}\text { - Yaşam döngüsü } \\
\text { sonunda tekrar } \\
\text { kullanıma } \\
\text { uygunluk; } \\
\text { - } \quad \text { Rekabetçi fiyat. }\end{array}$ \\
\hline
\end{tabular}

Tablo 2. Organik ve inorganik faz değiştiren malzemelerin karşılaştırılması [4,49,50]

Table 2. Comparison of organic and inorganic phase change materials[4,49,50]

\begin{tabular}{|c|c|}
\hline & Parafinler \\
\hline & $\begin{array}{l}\text { Yağ asitleri } \\
\text { esterleri }\end{array}$ \\
\hline $\begin{array}{l}\text { Organik } \\
\text { FDM'ler }\end{array}$ & Şeker alkoller \\
\hline & BioPCM'ler \\
\hline $\begin{array}{l}\text { İnorganik } \\
\text { FDM'ler }\end{array}$ & $\begin{array}{l}\text { Tuz hidratlar } \\
\text { Metalikleri }\end{array}$ \\
\hline
\end{tabular}

Mineral balmumu ve yağa verilen isimdir.

En yaygın kullanıma sahip FDM

19-24 ${ }^{\circ} \mathrm{C}$ faz değişimi sıcaklık aralığına sahip

Hammaddesi petrol olduğu için pahalı

Parafine benzer isı depolama yoğunluğu

Faz değişim sıcaklığ 1 parafinler gibi yüksek

Asidik yapıları nedeniyle çevre ile reaksiyona girmeye meyilli

Karbonhidratın D-sorbitol, ve xylitol gibi hidrojene edilmiş formudur.

Parafin ve yağ asitlerinden daha yüksek gizli isıya ve yoğunluğa sahiptirler.

$90{ }^{\circ} \mathrm{C}-200{ }^{\circ} \mathrm{C}$ arasındaki faz değișim sıcaklıkları nedeni ile bina uygulamaları için uygun değillerdir

Parafine alternatif olarak gida endüstrisi atık ürünlerinin kullanımı ile geliștirilmiş yeni bir FDM çeşididir.

Maliyeti daha düşük (hammaddesi petrol değil)

Parafin gibi yanıcı değil

Cevreci

Hayvan yağlarından, soya, kakao ve palm yağı gibi bitkisel yağlardan meydana gelir

Bozulmaya uğramadan binlerce kere faz değişimi geçirebilen zehirli olmayan bir malzeme

Sürdürülebilir

Binalarda en yaygın kullanılan inorganik FDM

Çok yüksek faz değişim sıcaklığına sahip olduğu için binalarda kullanıma uygun değil 
Tablo 2'nin devamı

Continue of Table 2

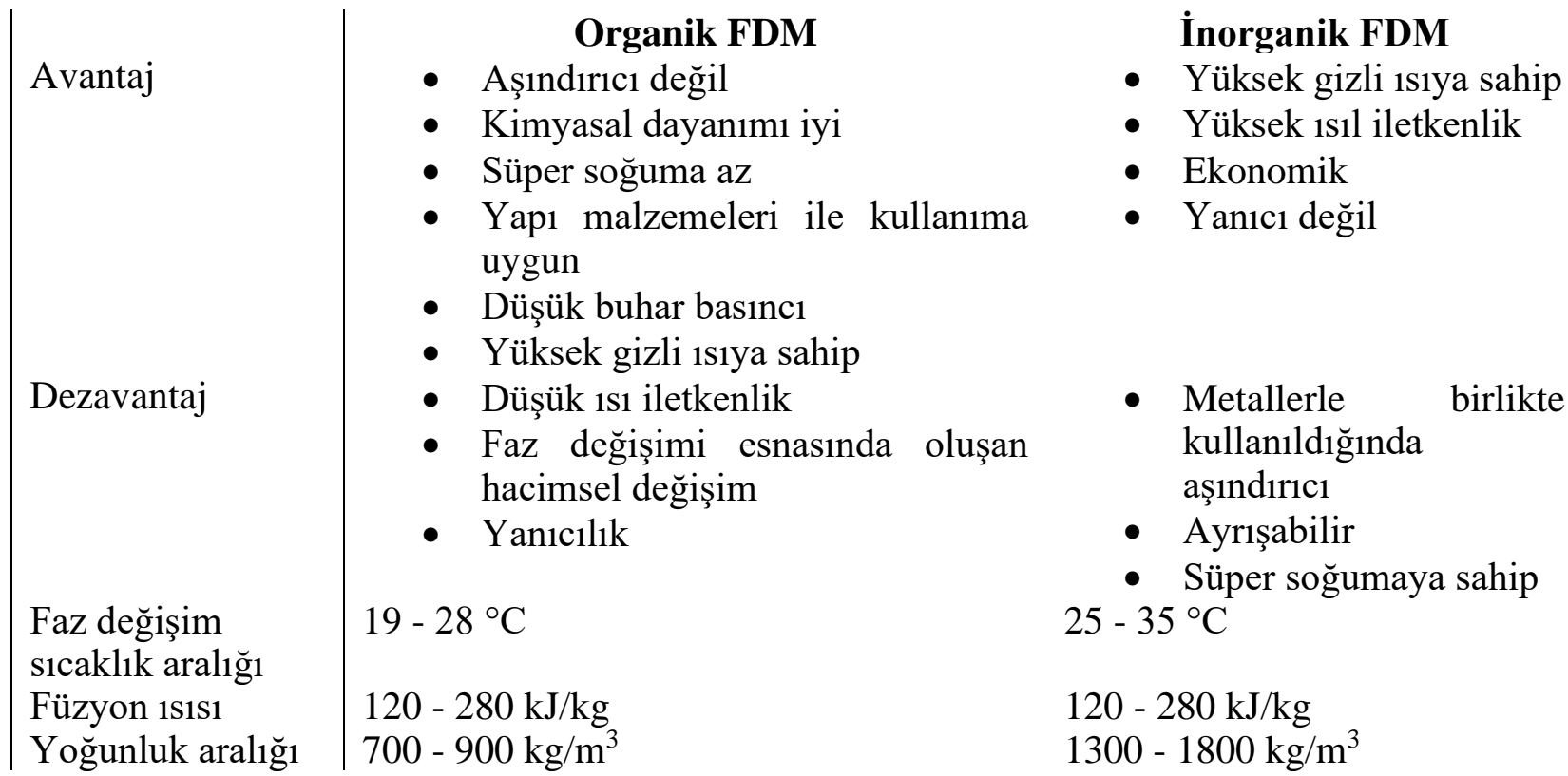

Literatürde yapılan çalışmalardan Şekil 2'de de görüldüğü gibi bina kabuğu uygulamalarında organik bazlı Parafin malzemenin en yaygın kullanılan FDM olduğu görülmüştür. Kullanımı yaygın olan diğer malzemeler sırasıyla inorganik bileşiklerden tuz hidratları ve parafine alternatif olarak son y1llarda geliştirilmiş yeni bir FDM çeşidi olan BioPCM'lerdir. Faz değiştiren malzemeler organik ve inorganik bileşikler olmak üzere iki sınıfa ayrılır. Tablo 2'de organik ve inorganik FDM'lerin karşılaştırılması yapılmıştır.

\section{FDM ile Birleştirme Teknikleri}

FDM'ler geleneksel yap1 malzemelerine doğrudan birleştirme, daldırma ve kapsülleme olmak üzere üç yöntem ile entegre edilir. Doğrudan birleştirme tekniğinde, sıvı veya toz FDM üretim sırasında alçı, beton veya sıva gibi inşaat malzemeleriyle doğrudan karıştırılırken; daldırma tekniğinde, alçı levha, tuğla veya beton blok gibi gözenekli yap1 malzemeleri, erimiş FDM' nin içine daldırılarak uygulanır $[41,43]$. Kapsülleme tekniği ise FDM' yi çevre ile zararlı etkileşimlerden korumak için bir engel görevi görerek, 1s1 transferi için yeterli yüzey alan1, yapısal dayanıklılık ve kolay kullanım sağlar. Mikro kapsülleme ve makro kapsülleme olmak üzere iki tip kapsülleme tekniği vardır. Mikro

kapsülleme, mikrometre ile milimetre aralığında üretilen kapsüller ile katı veya sıvı madde damlacıklarının tek tek kaplandığı işlem olarak tanımlanmaktadır. Şekil 3'te mikro kapsülleme tekniği ile uygulanmış parafinden oluşturulmuş kompozit bir duvar panosu görülmektedir. Şekil 3a.' da alçı sıvaya katılmış mikro kapsül FDM'lerin mikroskopik kamera (SEM) ile görünüşü verilmiştir. Şekil 3b.'de \%60 oranında mikro kapsüllenmiş parafinden oluşan FDM kompozit duvar panosu görülmektedir.

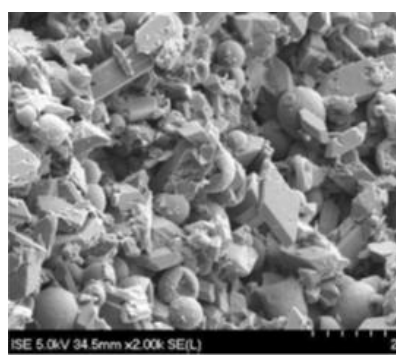
a) Şekil 3. (a) Alçı sıva içerisindeki mikro kapsüllerin SEM görünüşü [50], (b) \%60 oranında mikro kapsüllenmiş parafinden oluşan FDM kompozit duvar panosu [43].

Figure 3. (a) SEM appearence of microcapsuls in plaster [50], (b) PCM composite wall panel with parafin - ratio of $\% 60$ microcapsulated [43]. 
Şekil 4a' da tuğla içerisine makro kapsül şeklinde paketlenmiş parafin uygulaması [43] ve Şekil 4b'de makro kapsüllerde BioPCM görülmektedir.

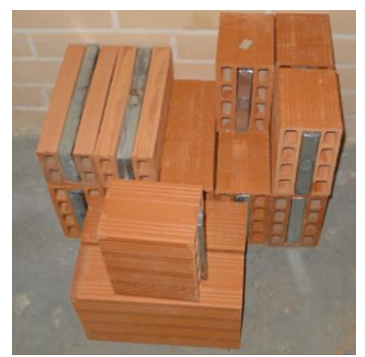

a)

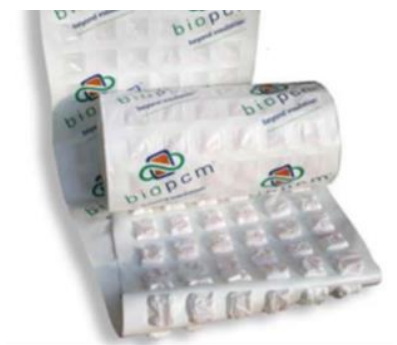

b)
Şekil 4. (a)Tuğla içerisine makro kapsül şeklinde paketlenmis parafin uygulaması [43], (b) makro kapsüllerde BioPCM.

Figure 4. (a) Application parafin macrocapsulated into brick [43],(b) BioPCM in macro capsuls.

Yapılan literatür çalışmalarından çıkarılan sonuç; Şekil 5'te de görüldüğü gibi bina uygulamalarında mikro kapsül tekniğinin en yaygın kullanılan teknik olduğunu göstermiştir.

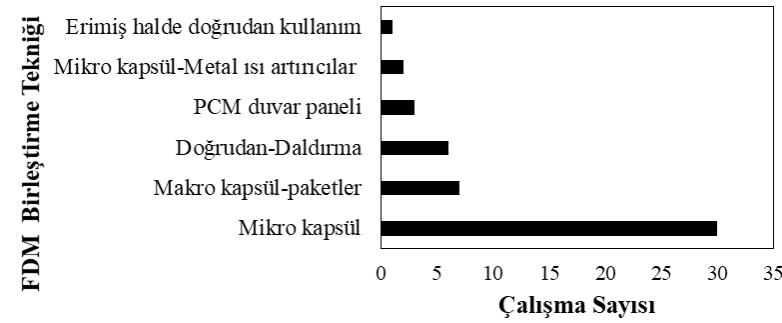

Şekil 5. Bina kabuğu uygulamalarında kullanılan FDM birleştirme teknikleri ve kullanılma yoğunluğu.

Figure 5. PCM joining techniques and using density using in building envelope practices.

Tablo 3'de FDM birleştirme tekniklerinin avantaj ve dezavantajlarının karşılaştırılması verilmiştir.
Tablo 3. FDM birleștirme tekniklerinin avantaj ve dezavantajlarının karşılaştırılması [4,49,50]

Table 3. Compared advantages and disadvantages of PCM joining techniques

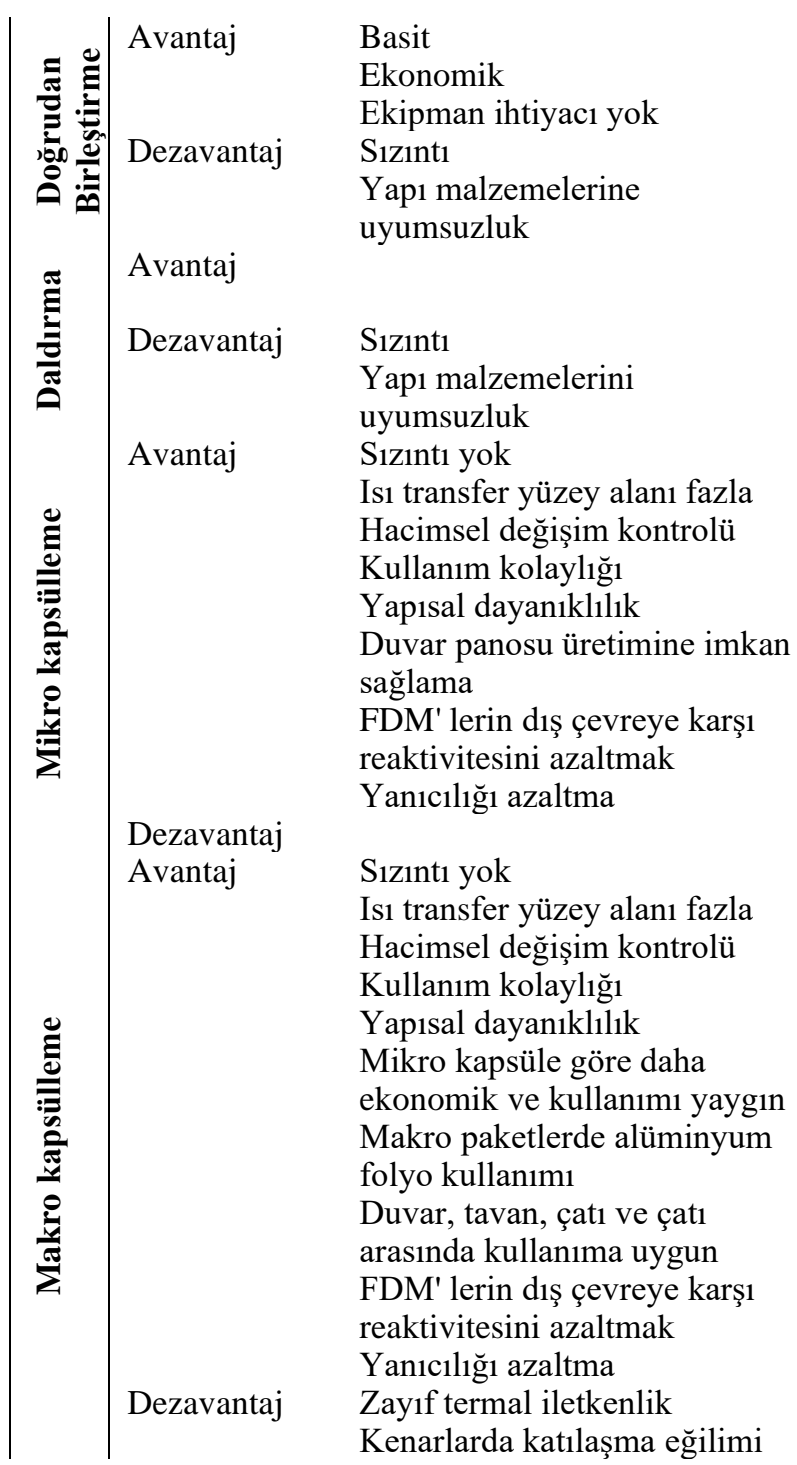

\section{Çalışma Tipleri ve Kullanılan Simülasyon Programları}

İncelenen bilimsel çalışmalarda çalışma tipi olarak Şekil 6'da görüldüğü gibi deney ve simülasyon yöntemlerinin birlikte kullanıldı ğ çalışmalar öne çıkmaktadır. Sadece simülasyon yönteminin tercih edildiği çalışmalar ikinci sırada yer alırken sadece deneysel çalışma tiplerinin az sayıda olması dikkat çekicidir. 


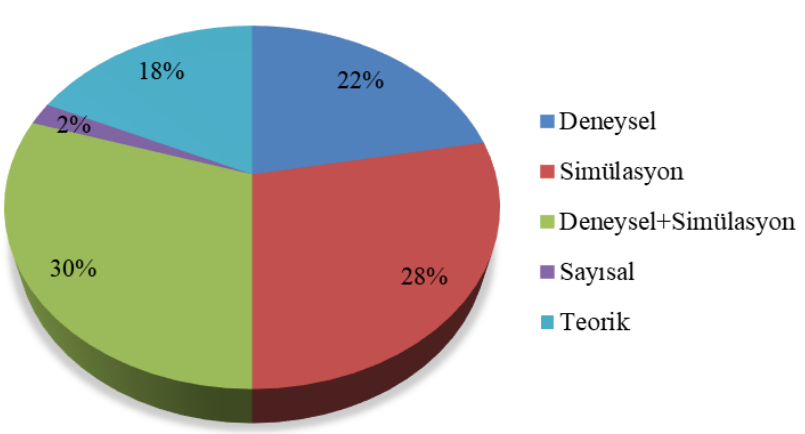

Şekil 6. Çalışma tipleri ve kullanım yoğunlukları

Figure 6. Study type and using density

Yapılan çalışmaların yaklaşık olarak \%60'ında simülasyon programı kullanımının tercih edilmesi doğru program seçiminin ne kadar önemli olduğunun göstergesidir. Bina kabuğu uygulamalarında saf FDM'ler çok nadir kullanılır. Onun yerine Şekil 3'te görüldüğü gibi karmaşık 1sıl karakteristiklere sahip daha fazla girdi gerektiren FDM'ler mikro veya makro kapsüllenmiş olarak kullanılmaktadır.Bu malzemelerden oluşan yapı elemanlarına ilişkin 1S1 transferi tek boyutlu olmamakta, 1sı köprüleri de dikkate alındığında hesaplanması oldukça karmaşık üç boyutlu isı transferleri meydana gelmektedir. $\mathrm{Bu}$ 1s1 transferlerinin hesaplamas1 oldukça karmaşıktır ve zaman gerektirir. Hesaplamaların doğruluğu kullanılan entalpi (enerji değişimi) verisinin güvenilirliği ile ilişskilidir. Sicaklığın bir fonksiyonu olarak ortaya çıkan entalpi çoğunlukla saf FDM'ler için diferansiyel 1s1l analiz (DTA) yöntemi ölçümlerinden elde edilir.

Bina bütününün veya bina kabuğu elemanının 1s1l ve enerji performans analizi için kullanılan DOE-2, EnergyPlus, BLAST, TRNSYS, ESP-r, MATLAB, RADCOOL, CLIM 2000, WUFI gibi farklı ticari programlar bulunmaktadır. Fakat sadece birkaçı kapsamlı bir şekilde faz değişim sürecini ve tüm binayı simüle edebilme özelliğine sahiptir. FDM entegre binaların tüm bina ölçeğinde simülasyonunu yapabilen en yaygın kullanılan simülasyon programları Tablo 4'te verilmiştir.
Tablo 4. FDM'lerin kullanıldı̆̆ bina kabuğunun enerji analizleri için bilinen en iyi simülasyon programlari [4]

Table 4. The best known that energy simulation softwares for energy analysis of building envelopes using PCM's

\begin{tabular}{|c|c|c|c|}
\hline 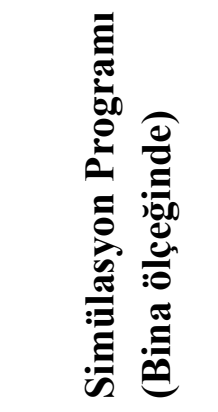 & 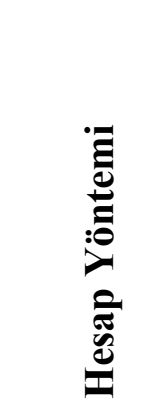 & $\begin{array}{l}0 \\
0 \\
0 \\
0 \\
0 \\
0\end{array}$ & \\
\hline ESP-r & $\begin{array}{l}\text { Etkin } \\
\text { 1s1 kap. }\end{array}$ & $\begin{array}{l}\text { Sonlu } \\
\text { Hacim }\end{array}$ & $\begin{array}{l}\text { Açık } \\
\text { (Explicit) }\end{array}$ \\
\hline TRNSYS & Etkin & Sonlu & Crank- \\
\hline $\begin{array}{l}\text { Tip 204- } \\
\text { Tip } 56\end{array}$ & 1s1 kap. & Eleman & Nicholson \\
\hline $\begin{array}{l}\text { TRNSYS } \\
\text { Tip 222- } \\
\text { Tip } 56\end{array}$ & $\begin{array}{l}\text { Dolaylı } \\
\text { Hesap. }\end{array}$ & - & - \\
\hline $\begin{array}{l}\text { TRNSYS } \\
\text { Tip 241- } \\
\text { Tip } 56\end{array}$ & $\begin{array}{l}\text { Entalpi } \\
\text { metodu }\end{array}$ & $\begin{array}{l}\text { Sonlu } \\
\text { Farklar }\end{array}$ & - \\
\hline $\begin{array}{l}\text { TRNSYS } \\
\text { Tip 260- } \\
\text { Tip } 56\end{array}$ & $\begin{array}{l}\text { Etkin } \\
\text { 1S1 kap. }\end{array}$ & $\begin{array}{l}\text { Sonlu } \\
\text { Farklar }\end{array}$ & $\begin{array}{l}\text { Açık } \\
\text { (Explicit) }\end{array}$ \\
\hline $\begin{array}{l}\text { TRNSYS } \\
\text { Tip 399- } \\
\text { Tip } 56\end{array}$ & $\begin{array}{l}\text { Isı kap. } \\
\text { göre iki } \\
\text { farklı } \\
\text { metod }\end{array}$ & $\begin{array}{l}\text { Sonlu } \\
\text { Eleman }\end{array}$ & $\begin{array}{l}\text { Crank- } \\
\text { Nichol. }\end{array}$ \\
\hline MATLAB & $\begin{array}{l}\text { Entalpi } \\
\text { metodu }\end{array}$ & $\begin{array}{l}\text { Sonlu } \\
\text { Hacim }\end{array}$ & $\begin{array}{l}\text { Crank- } \\
\text { Nichol. }\end{array}$ \\
\hline EnergyPlus & $\begin{array}{l}\text { Entalpi } \\
\text { metodu }\end{array}$ & $\begin{array}{l}\text { Sonlu } \\
\text { Farklar }\end{array}$ & $\begin{array}{l}\text { Kapalı } \\
\text { (İmplicit) }\end{array}$ \\
\hline
\end{tabular}

Yapılan literatür çalışmaları Şekil 7'de de görüldüğü gibi FDM'lerin kullanıldığı bina kabuklarının enerji analizleri için EnergyPlus'ın en fazla kullanılan simülasyon programı olduğunu göstermiştir. İkinci sırada ise yine 
EnergyPlus tabanlı bir yazılım aracı olan Design Builder programı yer almıştır.

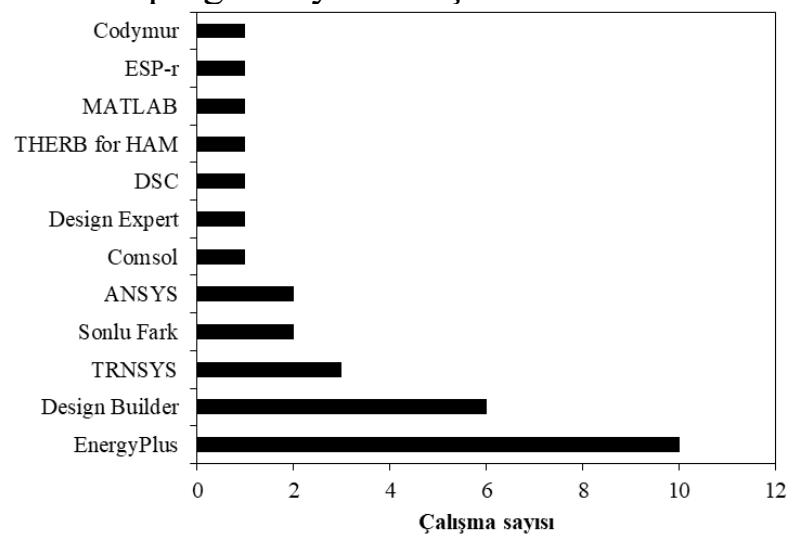

Şekil 7. Simülasyon programlarl ve kullanım yoğunluğu

\section{Figure 7. Simulation softwares and their using density}

EnergyPlus bina 1sitma, soğutma, aydınlatma, havalandırma ve diğer enerji akışlarını modellemek için Amerikan Enerji Bakanlığı tarafından geliştirilmiş ve sürekli geliştirilmekte olan kapsamlı bir bina enerji simülasyon programıdır. Binalardaki 1S1 transferinin modellenmesine olanak sağlarken aynı zamanda çok çeşitli HVAC ekipmanlarının da dikkate alınmasına imkan sağlar. Kapsamlı bina tasarım seçenekleri sayesinde bina enerji çalışmaları için güçlü ve ideal bir programdır. Çeşitli sistemlerden oluşan binaların 1sıtılması ve soğutulması için gerekli enerji hesaplamalarını gerçekleştirmek için birlikte çalışan birçok program modülünün toplamından oluşmaktadır. Temelde BLAST ve DOE-2 gibi en popüler erken dönem bina enerji simülasyon araçlarının bir benzeri olmasının yanı sira bir saatten daha az zaman dilimleri için hesaplama yapabilme özelliğine sahiptir. EnergyPlus ile modüler sistemler, 1sıl denge amacı ile kullanılan yeşil kabuk sistemler, fotovoltaik sistemler ve su bulunduran sistemler gibi birçok yeni sistemlerin simülasyonları yapılabilmektedir. Design Builder ise yapı tasarımlarının enerji, karbon, aydınlatma ve konfor açılarından performansını ölçmek ve kontrol etmek için geliştirilmiş EnergyPlus simülasyon motorunu kullanan bir yazılım aracidır [51].

\section{Çalışmalarda Kullanılan Laboratuar Ölçeğindeki Isıl Test Metotları}

FDM kullanımının önündeki en önemli engel maliyetinin yüksek olmasıdır. Bina kabuğu uygulamalarında FDM kullanımının maliyetini azaltmak için en etkili yöntem FDM'nin optimum konumu ve miktarının belirlenmesidir. $\mathrm{Bu}$ da FDM'nin 1sıl performans özelliklerinin çok iyi bilinmesi ve anlaşılması ile mümkündür. $\mathrm{Bu}$ nedenle FDM bazlı ürün ve sistemlerin ana termal karakterlerinin belirlenmesi için kısmen ucuz ve kullanımı kolay test yöntemleri mevcuttur. Bu yöntemler;

- Diferansiyel 1sil tarama kalorimetresi (DSC) yöntemi

- T-History yöntemi

- Dinamik Hot-Box yöntemleridir.

Yukarıdaki yöntemlerin özellikleri ve karşılaştırması ise Tablo 5'te verilmiştir.

\section{Faz Değiștiren Malzemelerle İlgili Yapılan Çalışmaların Değerlendirilmesi ve Tartışma}

$\mathrm{Bu}$ bölümde faz değiştiren malzemeler ile ilgili yapılmış ve bu çalışmanın temelini oluşturan 50 bilimsel yayın içerik olarak değerlendirilerek sonuçları karşılaştırılmıştır.

Bir çok çalışmada FDM' lerin Trombe duvarlarda kullanıldığı görülmüştür $[8,15,17,18,34,38,48]$. Çırakman [15] bir test odası inşa ederek güney duvarında mikrokapsül yöntemi ile duvar konstrüksiyonuna eklediği parafinin binanın enerji yüklerine etkisini deneysel olarak test etmiştir. Aylık ölçüm sonuçlarına göre 1sıtma enerjisine farklı aylarda \%4.3-\%70.4 aralığında katk1 sağladığ gözlenmiştir. Benzer bir başka çalışmada [16] aynı FDM malzemesinin soğutma enerjisine \%5$\% 10 ; 1$ sitma enerjisine ise \% 10-\%20 aralığında iyileştirme yaptığı sonucuna varılmıştır. Zalewski vd. [17], tuz hidratları makropaketler halinde birleştirerek FDM'li 2,5 cm kalınlığında bir trombe duvar oluşturmuşlardır. Yeni duvarın 15 $\mathrm{cm}$ kalınlığındaki beton duvara eşdeğer 1s1 depolama performansı gösterdiği ve depolanan enerjiyi iki kat daha hızlı bir şekilde mekana ilettiği sonucuna varmışlardır. Leang vd. [8], parafinin mikro paketler halinde kullanıldığ FDM'li bir kompozit Trombe duvar tasarlamış ve üzerinde deneysel bir çalışma yapmışlardır." 
Tablo 5. FDM entegre ürün ve sistemlerin ana termal karakterlerinin belirlenmesi için kullanılan test yöntemlerinin karşılaşıtırılması [4]

Table 5. Compared test methods using to determined of main thermal characters of product and systems entegrated PCM

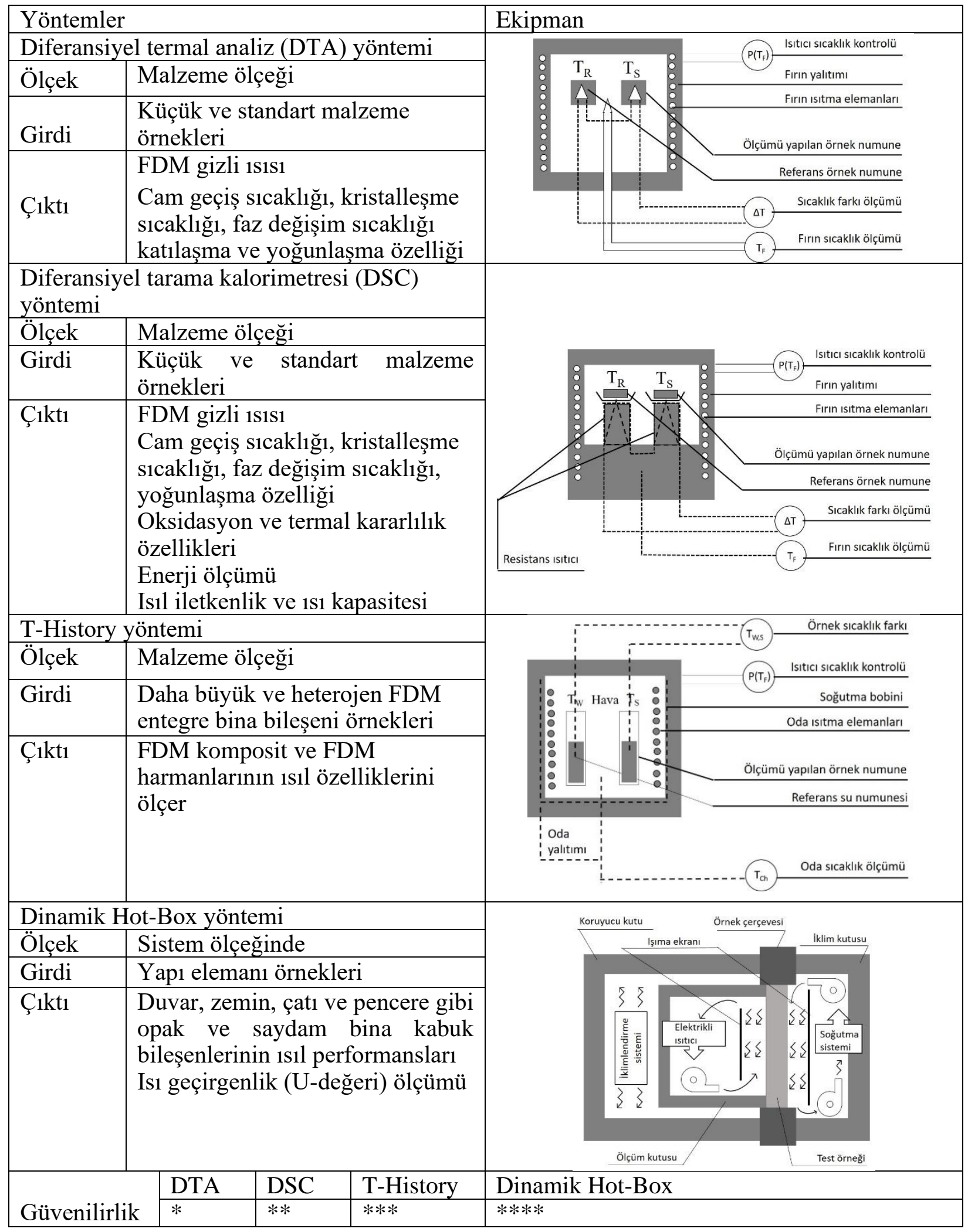


Küçük hacimde büyük miktarda 1s1 depolama kapasitesi elde etmek amacı ile yapılan deneysel çalışmada FDM ile bir yalıtım paneli birlikte kullanılarak bir pasif güneş bileşeni tasarlanmıştır. Yapılan çalışma sonucunda elde edilen trombe duvar bileşeninin kış gecelerinde 1sıl konfor sağlamak için çok uygun olduğu görülmüştür. Kompozit güneş duvarı 1sıyı 4 saatlik bir gecikme süresiyle serbest bırakmış ve iç mekanda istenmeyen aşırı 1sınmayı enerji katkılarını kontrol ederek önlemiştir. Ayrıca, FDM'li 1s1 depolama duvarının beton 1s1 depolama duvarından \%58 daha fazla 1sıy geri kazandığ 1 tespit edilmiştir.

Farklı iklimler için FDM'nin mevcut bina kabuklarının iç duvarlarında kullanılmasının sağlayacağı enerji tasarrufu potansiyeli yapılan çalışmalarla değerlendirilmiştir $[10,11,14,20$, 23, 30, 35, 36, 38, 39, 41-47]. Concordia Üniversitesi Güneş Simülatörü ve Çevre Odası araştırma tesisinde (SSEC, Montreal, Kanada) gerçekleştirilen bir deneysel çalışmada FDM levha, iklim odasına yerleştirilmiş $2.80 \mathrm{~m} \mathrm{x}$ $1.30 \mathrm{~m} \times 2.44 \mathrm{~m}$ iç ölçülere sahip bir test odasının arka duvarına yerleştirilmiştir. Ön cepheye sahip $2,2 \times 2,2 \mathrm{~cm}$ 'lik $1,1 \mathrm{~W} / \mathrm{m}^{2} \mathrm{~K}$ 1s 1 geçirgenlik katsayısına (U) sahip bir pencere yerleştirilmiştir. Test odası, $8.9 \mathrm{~m} \mathrm{x} 7.3 \mathrm{~m} \mathrm{x} 4.7$ $\mathrm{m}$ boyutlarında geniş iklim odasının içine yerleştirilmiştir. Çalışma sonucunda Montreal'de, güneş 1şınımının sınırlı olmasından dolayı FDM kullanımının en soğuk aylarda çok etkili olmadığı görülmüştür. Bununla birlikte çözüm, tüm yıl bazında değerlendirildiğinde yaklaşık olarak \% 20 enerji tasarrufu sağlamıştır [20].

Başka bir çalışmada [21] Kıbrıs'ta Akdeniz iklim koşullarındaki tipik bir konutun kabuğunda makro kapsüllenmiş FDM uygulaması deneysel olarak değerlendirilmiştir. Enerji oranı kontrol testi ve sicaklik seviyesi kontrol testi simülasyonları, Geçici Sistemler Simülasyon yazılımı (TRNSYS) kullanılarak gerçekleştirilmiştir. FDM' ler;

- Çift tuğla duvarın ortasına (bu yalnızca yeni bir konutta uygulanabilir),

- Duvarın iç tarafındaki tuğla ve sıva katmanı arasina (bu hem yeni hem de mevcut konutlarda uygulanabilir),
- Duvarın dış tarafındaki tuğla ve sıva katmanı arasina (bu hem yeni hem de mevcut konutlarda uygulanabilir)

olmak üzere üç farklı kabuk kesiti ile uygulanmıştır. BioPCM mat' lardan $29{ }^{\circ} \mathrm{C}$ erime noktasına sahip M91 ürünü uygulamada kullanılan FDM olarak seçilmiștir. Yapılan çalışmanın sonuçları Kıbrıs ikliminde FDM katmanının bir dıș duvar konstrüksiyonuna uygulandığında optimum konumunun, tuğla gövde malzemesi ile dıș sıva katmanı arasında olduğunu göstermiștir. Bu durum FDM' nin bu konumda güneş 1 șınımı ve sıcaklık gibi dış iklimsel ortam koșullarına daha fazla maruz kalmasi ve aktif hale gelmesi ile ilişkilendirilmiștir. Bu durumda \% 28,6 oranında enerji tasarrufu sağlanmıştır. Optimum FDM konumu daha sonra bir 1s1 yalitımı ile birleştirilmiş (1S1 yalıtım sıvası) ve sonuçlar deneysel olarak incelenmiştir. Isı yalıtımı sıvası ve FDM' in birlikte kullanıldığ 1 seçenek \% 67,6 'lık bir enerji tasarrufu sağlanabileceğini göstermiştir. Sadece yalıtımlı durum ile kombine durum arasındaki fark ise \% 2,7 ile 6,6 arasinda değişmiştir [21]. Yapılan bir diğer çalışmada Laaouatni vd.[22], sivı halde mekanik olarak kararlı bir FDM ile doldurulmuş dikey havalandırma boruları içeren bir "beton blok" geliştirmişlerdir. $\mathrm{Bu}$ çözüm, beton bloğun 1sıl davranışını incelemek ve bina içindeki sıcaklığın kontrolünü sağlamak için hem deneysel hem de sayısal olarak ele alınmıştır. Kullanılan beton blok $50 \mathrm{~cm}$ x $20 \mathrm{~cm}$ x $9.5 \mathrm{~cm}$ boyutlarında ticari içi boş bir bloktur. Geometrik olarak uzunluğu, genişliği ve yüksekliği sırasıyla $13 \mathrm{~cm}, 5 \mathrm{~cm}$ ve $17 \mathrm{~cm}$ olan 3 dikdörtgen boşluktan oluşmuştur. Havalandırma tüpleri olarak $2 \mathrm{~cm}$ çapında ve 1 mm kalınlığında PVC borular kullanılmıştır. Altı boruyu yerleştirmek için bloktaki üç boşluğun tabanında ikişer delik açılmıştır. Beton blok boşluklarında FDM doğrudan erimiș halde koyulmuştur. Kullanılan FDM, parafin ve stiren tipi polimer karışımıdır. Bu karışım, sızıntı sorunlarını önlemek için önemli olan yüksek bir mekanik stabiliteye sahiptir. Kullanılan parafin, $28^{\circ} \mathrm{C}$ 'lik bir faz değişim sıcaklığına ve $245 \mathrm{~kJ} /$ kg'llk bir gizli 1sıya sahip ticari bir üründür. Yapılan çalışmanın amacı, dışarıdan dayatılan 1sıl gerilmeleri emmek için duvarların 1sıl ataletini arttırmaktır. Önerilen metod ile FDM'in faz değişim yüzeyi havalandırma tüpleri aracılığı ile artırılmış, gündüz FDM'lerde depolanan 1s1 gece tüplerdeki hava aracılığıyla binadan 
uzaklaştırılmıştır. Sonuçlar, parafinin tüplerle yerleștirilmesinin, faz değişim sıcaklığı etrafında bir sicaklı seviyesine sahip olmasinı ve dolayısıyla uygulanan termal gerilmelerin sönümlenmesini mümkün kıldığını doğrulamıştır. 3D sayısal simülasyonlar, COMSOL Multiphysics yazılımı kullanılarak yapılmış, simülasyonlar ile deneysel sonuçlar arasında iyi bir uyum olduğu görülmüştür. Başka bir çalışmada [30], FDM entegre edilmiş bina kabuklarının klimanın sürekli ve aralıklı olarak çalıştırılması ile termal performans iyileştirmelerini incelemek için Sichuan Üniversitesi'nde, dinamik bir test deney binası inşa edilmiştir. Bina $3.5 \mathrm{~m} \times 3,0 \mathrm{~m}$ x $2,2 \mathrm{~m}$ boyutlarında ayrı iki odadan oluşmaktadır. Test sonuçlarının daha karşılaştırılabilir hale getirilebilmesi için $60 \mathrm{~cm} \times 60 \mathrm{~cm} \times 26 \mathrm{~cm}$ boyutlarındaki iki duvar ünitesinin aynı iç ve dış ortamda konumlanmalarına özen gösterilmiştir. Çelik çerçevelerle desteklenen bu iki duvar ünitesi, birimler arasındaki 1s1 transferini azaltmak ve her birinin merkezi alanında bir boyutlu 1s1 transferini sağlamak için $8 \mathrm{~cm}$ EPS 1s1 yalıtım katmanı ile çevrilmiştir. Kullanılan FDM'nin faz değişim sicaklık aralığ $18{ }^{\circ} \mathrm{C}$ ila 26 ${ }^{\circ} \mathrm{C}$ 'dir. Gizli 1sıs1 ise $178.5 \mathrm{~kJ} / \mathrm{kg}$ ' dir. Test duvar ünitelerinin yüzey sıcaklıklarını ölçmek için yerden 1,50 m yükseklikte iç ve dış yüzeylerin ortasına ve FDM iç ve dış yüzeyine 1sı sensörleri yerleştirilmiştir. İç yüzeylerin ortasına ayrıca 1sı akış ölçerler monte edilmiştir. Sıcaklık ve 1sı akışını ölçmek için \% 2 hassasiyetle ölçüm yapan T tipi termokuplar ve \% 5 hassasiyetle ölçüm yapan JTC08A model 1s1 debimetreler kullanılmıştır. Tüm ölçüm verileri bir JTRG-II bina termal sicaklık otomatik test cihazı tarafından kaydedilmiştir. Farklı klima koşullarında sıcaklık ve 1sı akışı değişikliklerinin ölçümleri Haziran 2015 - Ağustos 2015 tarihleri arasında dakikada bir gerçekleştirilmiştir. Soğutma termostatı ayarı, FDM' lerin faz değişimini sağlamak için $16^{\circ} \mathrm{C}^{\prime}$ ye ayarlanmıştır. Aralıklı iklimlendirme sırasında, iç yüzeye aktarılan soğuğun bir kısmı duvar tarafından depolanırken, diğeri duvar boyunca dış ortama kaybedilmiştir. FDM duvarına gelince, azalan sıcaklıkla FDM'ler sıvıdan katıya değişmiş ve soğuk depolanmış, klima durduktan sonra artan sıcaklık ile FDM'ler katıdan sıvıya değişmiş ve soğuk ortama geri birakılmıştır. Sonuçlar FDM'lerin iç yüzey sıcaklığını $1{ }^{\circ} \mathrm{C}$ azaltabildiğini ve FDM duvarının soğuk bırakma süresinin referans duvardan 2 saat daha uzun olduğunu göstermiştir. İç yüzey 1sı akışı sürekli klima ve aralıklı klima çalışma programının her ikisinde de yaklașık \% 40 azaltılabilmiștir. Aralıklı iklimlendirme ile, FDM duvar bünyesinde depolanan soğuğun soğutma durduktan sonra iç ortama birakıldığ görülmüştür. $\mathrm{Bu}$ nedenle, iklimlendirme işleminin makul bir şekilde kontrol edilmesi ile iklimlendirme süresi azaltılarak soğutma enerji tüketiminde belirli bir miktar verim elde edilebileceği gösterilmiştir [30].

Yapılan bir diğer çalışmada [32], farklı iklim koşulları altında FDM' in iç mekanda kullanımının termal konfor açısından sağlayacağı etki karşılaştırmalı olarak analiz edilmiştir. Bu kapsamda farklı iklim bölgelerine ait beş tipik şehir için EnergyPlus programı kullanılarak oluşturulan referans Model ve FDM Modelin simülasyonları yapılarak yıllık iç mekan 1sıl ortamları incelenmiştir. Daha sonra oluşturulan modelleri doğrulamak için, Sichuan Üniversitesi'nde iki hafif bina modeli (referans Model ve FDM Model) inşa edilmiștir. Model binaların büyüklüğü $800 \mathrm{~mm} \times 1000 \mathrm{~mm} \times 1300$ mm'dir. Çalışmada kullanılan FDM'nin faz değişimi sıcaklık aralığ $18{ }^{\circ} \mathrm{C}$ ila $26{ }^{\circ} \mathrm{C}$, gizli 1sıs1 ise $178.5 \mathrm{~kJ} / \mathrm{kg}$ dir [32]. Çalışmanın sonuçları, özellikle 1lıman bölgelerde FDM' nin iç mekan tepe sıcaklığını düşürebildiğini ve iç mekan sıcaklık dalgalanmalarını etkili bir şekilde azaltabildiğini göstermiştir. Ayrıca gece ve gündüz arasındaki dış hava sıcaklık farkının fazla olduğu iklimlerde, FDM' in faz değişim döngüsü tamamlanabildiği için daha fazla verim elde edilebileceği ortaya koyulmuştur.

Faz değiştiren malzemeler ile ilgili yukarıda detaylıca aktarılan çalışmalardan edinilen bilgiler 1şığında bu malzemelerin çoğunlukla mikro veya makro paketler halinde bina elemanı konstrüksiyonuna katıldığı, malzeme kullanımında daha çok parafinin seçildiği ancak yağ asidi ve tuz hidratlarında kullanıldığ 1 gözlenmiştir. FDM'nin faz değişim sıcaklığının bina uygulamalarına uygunluğunun dikkate alındığ 1 tüm çalışmalarda $18{ }^{\circ} \mathrm{C}-26^{\circ} \mathrm{C}$ sıcaklık aralıklarında değişime uğrayan malzemelerin tercih edildiği görülmüştür. Gündüz ve gece sıcaklık farklarının az olduğu 1lıman iklimlerde bile FDM ile ilgili yapılan çalışmalarda iyi bir performans elde edildiği sonucuna varılmıştır. 
$\mathrm{Bu}$ noktadan hareketle FDM'nin binalarda nerede kullanılacağı ve performans artışının ne oranda olacağı bilgisinin elde edilebilmesi için bu konuda yapılan deneysel çalışmaların hız kazanması gerekliliği üzerinde durulmalıdır. Literatürden elde edilen bilgiler ışığında faz değiştiren malzemelerle ilgili çalışmaya yeni başlayacak olan araştırmacılara izlemesi gerekli olan süreçler bir iş akış diyagramı üzerinde Şekil 8 'de gösterilmiştir. $\mathrm{Bu}$ diyagram sayesinde çalışma öncesinde alınması gerekli kararlar, izlenecek süreç özetlenmiş ve araştırmacılara yol gösterilmiştir.

\section{Sonuçlar}

Çalışma sonucunda incelenen bilimsel yayınlardan faz değiştiren malzemelerle ilgili olarak en fazla tercih edilen kullanım yeri, çeșidi, birleştirme tekniği, çalışma tipi ve simülasyon programı Tablo 6'da verilmiştir.

Tablo 6. Incelenen bilimsel yayınlardan elde edilen çıkarımlar

Table 6. Findings obtained from investigated scientific studies

\begin{tabular}{|c|c|}
\hline 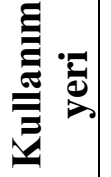 & Duvarlar \\
\hline 爷: & Parafin \\
\hline 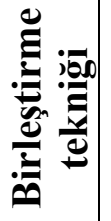 & Mikrokapsülleme \\
\hline 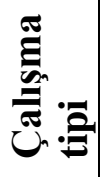 & Deneysel ve simülasyon \\
\hline 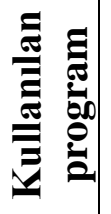 & EnergyPlus \\
\hline
\end{tabular}

Tablo 6'da görüldüğü gibi incelenen bilimsel çalışmalarda bina kabuğunun isıl kütlesini artırmak amacı ile faz değiștiren malzemeler en çok duvar bileșeninde kullanılmıștır. Parafinin en fazla tercih edilen ve üzerinde çalışmalar yapılan faz değiştiren malzeme çeşidi olduğu görülmüştür. Faz değiştiren malzemeleri bina bileșeni ile birleștirme tekniği olarak ise çoğunlukla mikro kapsülleme tekniği tercih edilmiştir. Ayrıca yapılan incelemelerde deneysel çalışma ve simülasyonun birlikte kullanıldığı çalışma tipinin en fazla tercih edilen çalışma tipi olduğu görülmüştür. Simülasyon programı olarak ise EnergyPlus, çalışmalarda en fazla kullanılan programdır.

Bilimsel çalıșmalar binalarda enerji tasarrufu için FDM'li yap1 elemanlarının nispeten iyi bir potansiyele sahip olduğunu göstermiștir. Günümüzde FDM hakkında yayınlanmış birçok araștırma olmasına rağmen bu konudaki mühendislik literatürünün yetersiz olduğunu belirtmek gerekir. Gerçek koșullarda yapılmıș daha fazla deneysel araştırma gerekliliği neredeyse bütün çalışmalarda vurgulanmıştır. FDM'nin her koşulda yapıda kullanıma uygun, düşük maliyetli ve sürdürülebilir bir malzeme olarak geliştirilmesi önem arz etmektedir. Temel FDM ürünleri için uzun dönem dayanıklılık kriterleri bugün oldukça iyi tanımlanmıştır. Ancak uzun dönem performans özellikleri FDM'li geliştirilmiş bina kabuğu için henüz tam olarak anlaşılamamıştır ve ilgili performans düzenlemeleri geliştirilmeyi beklemektedir. Ayrıca FDM'li geliştirilmiş bina bileşeninin kullanım ömrünün en az harmanlandığ malzemenin kullanım ömrü kadar olması gereklidir. Aksi durumda bina kullanım döneminde bakım ve onarım anlamında sorunlar yaşanması ihtimaldir. Tüm bu nedenlerden ötürü faz değiștiren malzemelerin binalarda kullanımıla ilgili özellikle deneysel çalışmaların hız kazanması ve avantajdezavantajlarının açık ve net olarak ortaya konulması gerekmektedir. 


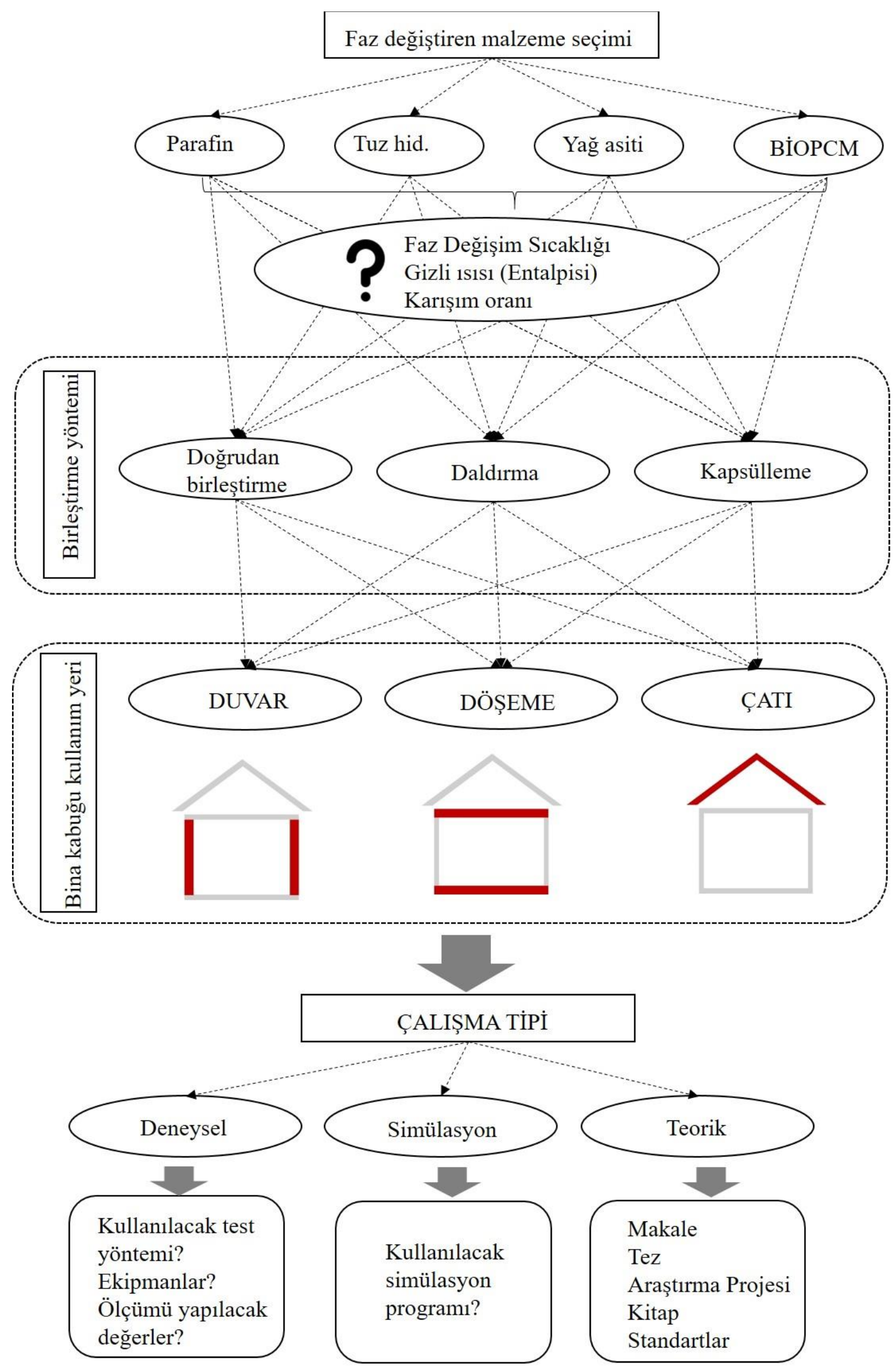

Şekil 8. FDM ile ilgili yapılacak çalışmalarda izlenmesi gereken süreç

Figure 8. Following process in studies on PCM 


\section{Kaynaklar}

[1] BP Energy Outlook 2019 Edition, https:// www.bp.com/content/dam/bp/business-sites /en /global/ corporate/ pdfs/ energy-economics/ energyoutlook/ bp-energy-outlook-2019. pdf, 13.06.2020.

[2] Directive 2010/31/EU, Energy performance of buildings, European Parliament and of the Council.

[3] Ulusal Enerji Verimliliği Eylem Planı 2017-2023, T.C. Enerji ve Tabii Kaynaklar Bakanlığı, Mart 2018, Ankara.

[4] Kosny, J., PCM- Enhanced Building Components, Springer, Switzerland, 2015.

[5] http:/www.dspace.library.cornell.edu/bitstream/1813 /125/2/Igloo.pdf.

[6] Gonzales-Espada, W.J., Bryan, L.A., Kang N-H., (2001). The intriguing physics inside an Igloo, Physics Education, 36,4, 290-298.

[7] Telkes, M., (1978). Trombe wall with phase change storage material. In: Proceedings of the 2 nd national passive solar conference, Philadelphia.

[8] Leang,P.T., Zalewski, L., Enghok, S.L., (2017). Numerical Study Of A Composite Trombe Solar Wall İntegrating Microencapsulated (PCM), Energy Procedia, 122, 1009-1014.

[9] Graciaa, A.D., Cabeza, L.F., (2015). Phase change materials and thermal energy storage for buildings, Energy and Buildings, 103, 15, 414-419.

[10] Kuznik, F., Virgone, J., Noel, J., (2008). Optimization of a phase change material wallboard for building use,Applied Thermal Engineering, 28,11-12, 12911298.

[11] Kuznik,F., Virgone, J., Roux, J.-J. (2008). Energetic efficiency of room wall containing fdm wallboard: a full-scale experimental investigation, Energy and Buildings, 40 ,2, 148-156.

[12] Tokuç, A.,(2013). Faz değişim malzemelerinin 1sıl enerji depolama amaciyla yap1 elemanlarında kullanılması, Dokuz Eylül Üniversitesi / Fen Bilimleri Enstitüsü / Mimarlık Bölümü / Yapı Bilgisi Anabilim Dalı, Doktora Tezi.

[13] Kancane,L., Vanaga,R., Blumberga, A., (2016). Modeling of building envelope's thermal properties by applying phase change materials, Energy Procedia, 95 , 175 - 180.

[14] Evola, G., Marletta, L., Sicurella, F., (2013). A methodology for investigating the effectiveness of PCM wallboards for summer thermal comfort in buildings, Building Environment, 59, 517-527.

[15] Çırakman, A.K.,(2010). Faz değiştiren madde içeren bina güney duvarının deneysel olarak incelenmesi,
Atatürk Üniversitesi / Fen Bilimleri Enstitüsü / Makine Mühendisliği, Doktora Tezi.

[16] Konuklu, Y., (2008). Mikrokapsüllenmiş Faz değiştiren maddelerde termal enerji depolama ile binalarda enerji tasarrufu, Çukurova Üniversitesi / Fen Bilimleri Enstitüsü / Kimya Anabilim Dalı, Doktora Tezi.

[17] Zalewski,L., Joulin, A., Lassue, S., Dutil,Y., Rousse, D.,(2012). Experimental study of small-scale solar wall integrating phase change material.

[18] Fiorito, F., (2012). Trombe walls for lightweight buildings in temperate and hotclimates. exploring the use of phase change materials for performances improvement, Energy Procedia, 30, 1110 - 1119.

[19] Diaconu, B.M., Cruceru, M., (2010). Novel concept of composite phase change material wall system for year-round thermal energy savings, Energy and Buildings, 42, 10, 1759-1772.

[20] Guarino, F., Dermardiros, V., Chen,Y., Rao, J., Athienitis,A., Cellura, M., Mistretta, M., (2015). PCM thermal energy storage in buildings: experimental study and applications, Energy Procedia, 70, 219 - 228.

[21] Panayiotou, G.P.,Kalogirou, S.A., Tassou, S.A., (2016), Evaluation of the application of phase change materials (PCM) on the envelope of a typical dwelling in the mediterranean region, Renewable Energy, 97,24-32.

[22] Laaouatni, A., Martaj, N., Bennacer, R., Mohamed Mohammed, E.O., Ganaoui, E., (2017). Phase change materials for improving the building thermal inertia, Energy Procedia, 139, 744-749.

[23] Wu, Z., Chen, M.Q.Z., (2017). Phase change humidity control material and its application in buildings, Procedia Engineering, 205, 1011-1018.

[24] Ramakrishnan, S., Wang, X., Sanjayan, J., Wilson, J., (2016). Experimental and numerical study on energy performance of buildings integrated with phase change materials, Energy Procedia, 105, 2214 -2219 .

[25] Han, Y., Taylor, J.E., (2015). Simulating the impact of phase change material embedded building envelopes on the inter-building effect in non-tropical cities, Procedia Engineering, 118, 760 - 765.

[26] Nazi,W.I.W.M., Wang,Y., Chen,H., Zhang,X., Roskilly,A.P., (2017). Passive cooling using phase change material and insulation for high-rise office building in tropical climate, Energy Procedia, 142, 2295-2302.

[27] Li, Y., Darkw, J., Su, W., (2019). Investigation on thermal performance of an integrated phase change material blind system for double skin façade buildings, Energy Procedia, 158, 5116-5123. 
[28] Auzeby,M., Wei, S., Underwood, C., Chen, C., Ling,H., Pan, S., Ng, B., Tindall, J., Buswell, R., (2017). Using phase change materials to reduce overheating issues in uk residential buildings, Energy Procedia, 105, 4072 - 4077.

[29] Mols,T., Dzene,K.P., Vanaga,R., Freimanis, R., Blumberga, A., (2018). Experimental study of smallscale passive solar wall module with phase change material and fresnel lens, Energy Procedia, 147,467473.

[30] Li,Y., Liang, W., Zhou, J., Long,E., (2017). Experimental Study On Thermal performance improvement of building envelopes integrated with phase change materials in an air-conditioned room, Procedia Engineering, 205,190-197.

[31] Guarino, F.,, Cellura, S.L.M., Mistretta, M., La Rocca, V., (2015). Phase change materials applications to optimize cooling performance of buildings in the mediterranean area: a parametric analysis, Energy Procedia, 78, 1708 - 1713.

[32] Li, Y., Wang,Y., Meng, X., Wang, M., Long, E., (2015). Research on indoor thermal environment improvement of lightweight building integrated with phase change material under different climate conditions, Procedia Engineering, 121, 1628 - 1634.

[33] Bejan, A.S., Catalina, T., (2016). The implementation of phase changing materials in energy efficient buildings. case study: efden project, Energy Procedia, 85,52 - 59 .

[34] Ma, Q., Fukuda,H., Wei, X., Hariyadi,A., (2018). Optimizing energy performance of a ventilated composite trombe wall in an office building, Renewable Energy, 134, 1285-1294.

[35] Meng,E., Yu,H., Zhou, B., (2017). Study of the thermal behavior of the composite phase change material (fdm) room in summer and winter, Applied Thermal Engineering, 126, 212-225.

[36] Soudian,S., Berardi, U., (2017). Experimental investigation of latent thermal energy storage in highrise residential buildings in toronto, Energy Procedia, 132, 249-254.

[37] Xie,J., Wang,W., Liu,J., Pan, S., (2018). Thermal performance analysis of fdm wallboards for building application based on numerical simulation, Solar Energy, 162, 533-540.

[38] Li, S., Zhu, N., Hu,P., Lei, F., Deng,R., (2019). Numerical Study On Thermal Performance Of PCM Trombe Wall, Energy Procedia, 158, 2441-2447.

[39] Sajjadian, S.M., Lewis, J., Sharples, S., (2015). The potential of phase change materials to reduce domestic cooling energy loads for current and future uk climates, Energy and Buildings, 93, 83-89.

[40] Principi, P., Di Perna, C., Borrelli, G., Carbonari, A., (2005).Experimental energetic evaluation of changeable thermal inertia fdm containing walls, 482 th International Conference "Passive and Low Energy Cooling for the Built Environment, Santorini, Greece.

[41] Schossig, P., Henning, H.-M., Gschwander, S., Haussmann, T., (2005). Microencapsulated phasechange materials integrated into construction materials, Solar Energy Materials and Solar Cells, 89 (2-3), 297-306.

[42] Zhou, D., Zhao, C.Y., Tian, Y., (2012). Review on thermal energy storage with phase change materials (PCMs) in building applications, Applied Energy, 92, 593-605.

[43] Soares, N., Costa, J.J., Gaspar, A.R., Santos, P.,(2013). Review of passive PCM latent heat thermal energy storage systems towards buildings' energy efficiency, Energy and Buildings, 59, 82-103.

[44] Karaoulis, A., (2017). Investigation of energy performance in conventional and lightweight building components with the use of phase change materials (PCMs): energy savings in summer season, Procedia Environmental Sciences, 38, 796 - 803.

[45] Köse, E., Manioğlu G., (2018). Evaluation of the performance of phase change materials in relation to balanced distribution of heating energy cost in residential buildings, 13th International $\mathrm{HVAC}+\mathrm{R}$ Technology Symposium.

[46] Mays, A.I., Ammar, R., Hawa, M., Farouk,M.A.A., (2017). Using phase change material in under floor heating, Energy Procedia, 119, 806-811.

[47] Alama, M., Sanjayan,J., Patrick, X.W., Ramakrishnan, Z.S., Wilson,J., (2016). A Comparative study on the effectiveness of passive and free cooling application methods of phase change materials for energy efficient retrofitting in residential buildings, Procedia Engineering, 180, 993 -1002 .

[48] Knowles, T., (1983). Proportioning composites for efficient thermal storage walls, Solar Energy,31,3, 319-326.

[49] Farid, M.M., Khudhai, A.M., Ali, S., Razack, K., (2004). A review on phase change energy storage: materials and applications, Energy Conversion and Management, 45, 1597-1615.

[50] Cui,Y., Xie, J., Liu,J., Pan,S., (2015). Review of phase change materials integrated in building walls for energy saving, Procedia Engineering, 121,763770

[51] https://www.altensis.com/hizmetler/designbuildersoftware/

[52] Cellat, K., (2017). Binalarda enerji tasarrufu için güneş enerjisini faz değiştiren maddede pasif depolayan yeni beton karışımların geliştirilmesi ve uygulanması, Çukurova Üniversitesi / Fen Bilimleri Enstitüsü / Kimya Anabilim Dalı Doktora Tezi. 
[53] Farid, M.M., Khudhair, A.M., Razack, S.A.K., AlHallaj, S., (2004). A review on phase change energy storage: materials and applications, Energy Conversion and Management,45, 1597-1615.

[54] Velraj, R., Pasupathy, A., Phase change material based thermal storage for energy conservation in buildingarchitecture,https://www.researchgate.net/pu blication/228823294, 2006.

[55] Madessa, H.B., (2014). A review of the performance of buildings integrated with phase change material: opportunities for application in cold climate, Energy Procedia, 62, 318 - 328.

[56] Navarro,L., Garcia, A.D., Solé, C., , Castell,A., Cabeza,L.F., (2012).Thermal loads inside buildings with phase change materials: experimental results, Energy Procedia, 30, 342 - 349.
[57] Hanchi, N., Hamza,H., Lahjomri, J., Oubarra,A., (2017). Thermal behavior in dynamic regime of a multilayer roof provided with two phase change materials in the case of a local conditioned, Energy Procedia, 139, 92-97.

[58] Cao,V.D., Pilehvar,S., Salas-Bringas,C., Szczotok, A.M., Rodriguez, J.F., Carmona, M., Al-Manasir, N., Kjøniksen, A.L., (2017). ). Microencapsulated Phase Change Materials For Enhancing The thermal performance of portland cement concrete and geopolymer concrete for passive building applications, Energy Conversion and Management, 133,56-66.

[59] Pisello,A.L., Castaldo, V.L., Cotana,F., (2015). Dynamic thermal-energy performance analysis of a prototype building with integrated phase change materials, Energy Procedia, 81, $82-88$. 